\title{
PENGARUH KINERJA KARYAWAN DAN KUALITAS PELAYANAN TERHADAP KEPUASAN PENGGUNA JASA DRIVE THRU TAHUN 2020
}

\author{
Freda Habib ${ }^{1}$, Yulianti Keke ${ }^{2}$, Devi Ratnasari ${ }^{3}$ \\ 1,2,3 Manajemen, Fakultas Manajemen dan Bisnis, Institut Transportasi dan Logistik Trisakti, Jakarta, Indonesia \\ Email: 'habibfreda@gmail.com; ${ }^{2}$ yuliakeke@gmail.com; ${ }^{3}$ devira492@gmail.com \\ *Penulis korespondensi
}

\begin{abstract}
ABSTRAK
Unit Pengelola Pengujian Kendaraan Bermotor Pulogadung yang bergerak di dalam pengujian kendaraan bermotor. Pada penelitian ini, peneliti mencoba mengetahui tingkat kepuasan pengguna jasa yang diberikan oleh Unit Pengelola Pengujian Kendaraan Bermotor Pulogadung dilihat dari sisi Kinerja Karyawan dan Kualitas Pelayanan. Penelitian bertujuan untuk mengetahui dan menganalisis pengaruh dari Kinerja karyawan dan kualitas Pelayanan terhadap kepuasan pengguna jasa baik secara parsial maupun simultan. Dalam penelitian ini, peneliti menggunakan metode kuantitatif. Peneliti menganalisis data dari 97 pengguna jasa di Unit Pengelola Pengujian Kendaraan bermotor Pulogadung. Hasil penelitian bahwa Kinerja karyawan berpengaruh positif dan signifikan secara parsial terhadap variabel kepuasan pengguna jasa ditandai dengan nilai $\mathrm{t}$ hitung sebesar 13.695 dengan taraf signifikan sebesar 0,000 lebih kecil dari 0,05, Kualitas pelayanan berpengaruh positif dan signifikan secara pasrsial terhadap variabel kepuasan pengguna jasa di tandai dengan nilai t hitung sebesar 16.711 dengan taraf signifikan sebesar 0,000 lebih kecil dari 0,05 dan Kinerja karyawan dan kualitas pelayanan positif dan signifikan secara simultan terhadap variabel kepuasan pengguna jasa di tandai dengan nilai f hitung sebesar 146.823 dengan tariff signifikan sebesar 0,000 lebih kecil dari 0,05. Maka dari hasil, peneliti memberikan saran agar Unit Pengelola Pengujian Kendaraan Bermotor Pulogadung bisa meningkatkan kepuasan Pengguna jasa dengan menerapkan strategi komunikasi dengan perencanaan dan manajemen, sehingga unit Pengelola Pengujian Kendaraan Bermotor Pulogadung dapat meningkatkan kualitas pelayanan yang lebih baik kepada pelanggan.
\end{abstract}

Kata kunci: Kinerja Karyawan, Kualitas P elayanan, Kepuasan, drive thru, strategi komunikasi.

\begin{abstract}
Pulogadung Motor Vehicle Testing division which is engaged in testing motorized vehicles. In this study, researchers tried to determine the level of satisfaction of service users provided by the Pulogadung Motor Vehicle Testing Management Unit in terms of Employee Performance and Service Quality. This study aims to determine and analyze the effect of employee performance and service quality on service user satisfaction either partially or simultaneously. In this study, researchers used quantitative methods. Researchers analyzed data from 97 service users in the Pulogadung Motor Vehicle Testing Management Unit. The results showed that employee performance had a positive and partially significant effect on the service user satisfaction variable marked by the t value of 13,695 with a significant level of 0,000 less than 0.05, the service quality had a positive and partially significant effect on the service user satisfaction variable marked with a t count value of 16,711 with a significant level of 0,000 less than 0.05 and employee performance and service quality are positive and significant simultaneously to the service user satisfaction variable marked with a calculated $f$ value of 146,823 with a significant tariff of 0,000 smaller than 0, 05. So from the results, researchers provide suggestions for the Pulogadung Motor Vehicle Testing Management Unit to increase service user satisfaction by implementing several communication strategies, such as planning and management, so that the Pulogadung Motor Vehicle Testing Management unit can improve the quality of better service to customers.
\end{abstract}

Keywords: Employee Performance, Service Quality, Customer Satisfaction, Drive Thru Communication Strategy.

\section{PENDAHULUAN}

Dinas Perhubungan Provinsi DKI Jakarta memiliki 4 tempat pengujian kendaraan bermotor (PKB) untuk melayani proses uji berkala seluruh kendaraan bermotor wajib uji (KBWU) yang berdomisili di wilayah Provinsi DKI Jakarta yaitu: (1) pengujian kendaraan bermotor Pulogadung, (2) Pengujian Kendaraan Bermotor Wil I. Ujung Menteng, (3) Pengujian Kendaraan Bermotor Wil. III Kedaung
Angke, (4) Pengujian Kendaraan Bermotor Cilincing, Paska penutupan Pengujian Kendaraan Bermotor Jagakarsa (2012), maka terjadi penumpukan dalam jumlah kendaraan yang ingin di uji kir berkala pada Unit Pengelolaan Pengujian Kendaraan Bermotor Pulogadung. Setiap unit pengelola pengujian kendaraan bermotor sudah ditentukan masing-masing kuotanya, kuota uji kir berkala di Unit Pengelola Pengujian Kendaraan Bermotor Pulogadung sendiri dapat menampung 310 kendaraan per hari namun 
terkadang terjadi lonjakan kendaraan pada setiap harinya, dan juga dipengaruhi oleh keterbatasan lajur uji mekanis Unit pengelola pengujian kendaraan bermotor pulogadung hanya memiliki 4 lajur mekanis yaitu : lajur uji mobil baru, laju uji mobil berkala, lajur uji bus, dan lajur uji kajen IV, yang mengakibatkan kendaraan tidak bisa melakukan pengujian dengan cepat dan terjadinya antrian kendaraan yang panjang, antrian panjang pun disebabkan oleh kurangnya lahan yang memadai. Strategi komunikasi merupakan hal yang harus di perhatikan oleh organisasi atau perusahaan jasa pelayanan, termasuk pelayanan pada perbankan. Strategi komunikasi adalah perencanaan (planning) dan manajemen (management) untuk mencapai tujuan. Dalam aspek pelayanan pasti ada tingkat kepuasan untuk pengguna jasa tersebut, Apabila tingkat kinerja melebihi harapan maka pengguna jasa akan merasa puas dan apabila tingkat kinerja tidak sesuai dengan harapan maka pengguna jasa akan kecewa, fakor yang menentukan tingkat kepuasan pelanggan pada unit pengelola pengujian kendaraan bermotor Pulogadung seperti pelayanan uji berkala yang sesuai dengan standar pelayanan yaitu maxsimal 37 menit, pelayanan yang baik, prosedur yang memudahkan pelanggan. Sedangkan yang terjadi pelayanan uji berkala dari drive thru in dan sampai pengambilan hasil uji di drive thru out bisa memakan waktu 2 jam, dan masih ada pengguna jasa yang kurang memahami prosedur pelayanan sehingga masih adanya ketidakpuasan pelanggan. Keberhasilan pelaksanaan pelayanan tidak terlepas dari factor komunikasi Komunikasi berperan sangat besar dalam meningkatkan kualitas pelayanan publik. (Meriyadi, Ali, \& Jusni, 2019). Komunikasi sangat berpengaruh terhadap kualitas pelayanan public dan ditentukan opleh dimensi komunikator, media, pesan, komunikan dan efek (Hardiyansyah, 2011). Namun apabila kinerja karyawan ditingkatkan akan mendapatkan hasil yang baik dan akan timbul kepuasan pelanggan itu sendiri dan banyak manfaat apabila timbul kepuasan pelanggan bisa membanggakan Dinas Perhubungan Provinsi DKI Jakarta dan transportasi provinsi DKI Jakarta sebagai pengawas dan pelaksana. Kinerja menjadi cerminan kemampuan dan keterampilannya dalam pekerjaan tertentu yang akan berdampak pada reward dari perusahaan. Oleh sebab itu karyawan harus meningkatkan dalam melayani pengguna jasa dengan baik dan melayani secara cepat dan tepat agar sesuai dengan waktu standar pelayanan yang sudah ditentukan, namun terkadang cepat atau tidaknya waktu penyelesaian pengujian disebabkan dengan fasilitas yang masih kurang cepat dalam menangani pelayanan. Berdasarkan uraian masalah dan teori yang telah dibahas diatas maka penulis membuat hipotesis untuk variabel yang diteliti.
Dimana untuk memberikan jawaban sementara atau perkiraan pemecahan masalah adalah sebagai berikut:

H1: Terdapat pengaruh signifikan antara Kinerja karyawan terhadap Kepuasan pengguna jasa

$\mathrm{H} 2$ : Terdapat pengaruh signifikan antara kualitas pelayanan terhadap Kepuasan pengguna jasa

H3: Terdapat pengaruh signifikan antara Kinerja karyawan dan Kualitas pelayanan terhadap Kepuasan Pengguna jasa.

\section{KERANGKA TEORI}

\subsection{Kinerja Karyawan}

Gibson (2018) kinerja karyawan adalah untuk kerja yang dilakukan seorang karyawan yang berkualitas menyelesaikan pekerjanya dalam suatu organisasi sehingga tujuan yang diharapkan dapat tercapai secara efisien dan efektif. (Damayanti et al., 2018) mendefinisikan kinerja karyawan adalah hasil kerja secara kualitas dan kuantitas yang dicapai oleh seseorang karyawan dalam melaksanakan tugasnya sesuai dengan tanggung jawab yang diberikan kepadanyaKinerja karyawan adalah hasil kerja yang sudah dilakukan oleh para karyawan dan yang selalu di harapkan dengan hasil yang baik dan tepat sesuai dengan tujuan masing masing perusahaan.

\subsection{Kualitas Pelayanan}

Kualitas pelayanan menurut Kotler dan Keller (2012:83) mendefisikan pelayanan adalah seperti tindakan atau kegiatan yang dapat ditawarkan oleh suatu pihak kepada pihak lain yang pada dasarnya tidak berwujud dan tidak mengakibatkan kepemilikan apapun. pada Unit Pengelola Pengujian Kendaraan Bermotor Pulogadung itu sendiri masih kurangnya loket drive thru in sehingga satu loket tidak hanya melayani satu jenis kendaraan saja itu salah satu penyebab masih terjadi antrian kendaraan, fasilitas yang masih kurang mendukung juga berpengaruh terhadap kepuasan pengguna jasa seperti lamanya sistem input output menyebabkan hasil uji lama di terima di loket drive thru out, yang seharusnya di drive thru out melayani 1 kendaraan hanya 7 menit dengan menunggu hasil uji bisa memakan 10 menit bahkan lebih, sering terjadi alat pengujian yang rusak sehingga tidak bisa digunakan untuk menguji sehingga ditutupnya lajur pengujian dialihkan dengan lajur lain. (Tanod et al., 2018) kualitas layanan adalah tingkat keunggulan yang diharapkan dan kontrol atas tingkat keunggulan untuk memenuhi keinginan pelanggan. kualitas pelayanan adalah hasil kerja seseorang atau kelompok dalam mengerjakan suatu pekerjaan agar tercapainya satu tujuan dengan efektif, efisien dan tanggung jawab, kualitas, kuantitas, ketepatan waktu, efektivitas biaya sebagai dimensi. 


\subsection{Kepuasan Pengguna}

Sangadji (2018) memaparkan bahwa kepuasan pelanggan adalah perasaan senang atau kecewa seseorang dalam perbandingan antara kesennya konsumen terhadap tingkatan kinerja produk dan jasa ril atau aktual dengan kinerja sesuai harapan. kepuasan adalah kesenang dan keyakinan para pengguna jasa terhadap yang telah di terima pengguna jasa tersebut dan tingat perasaan konsumen setelah membandingkan antara apa yang dia terima dan harapkan.

\section{METODE PENELITIAN}

Penelitian ini dilakukan di Unit Pengolala Pengujian Kendaraan Bermotor Pulogadung. Penelitian dilakukan dengan cara menyebarkan kuisioner secara langsung kepada para pengguna jasa. Untuk mendapat informasi mengenai pelayanan di Unit Pengelola Pengujian Kendaraan Bermotor Pulogadung. dalam hal ini yang menjadi populasi adalah pengguna jasa Unit Pengelola Pengujian Kendaraan Bermotor Pulogadung yang ingin melakukan pengujian berkala yang berjumlah 97 responden yang di ketahui dengan rumus Slovin. Kuesioner yang akan di bagikan akan menggunakan metode analisis skala Likert Dalam penelitian ini penulisan mengunakan beberapa teknik analisis data dengan menggunakan:

1. Analisis regresi linier sederhana, yang digunakan untuk mendapatkan hubungan matematis dalam bentuk suatu persamaan antara variabel tak bebas dengan variabel bebas tunggal

2. Analisis Regresi Linier Berganda

Menurut sugiyono (2014, p. 277) analisis regresi linier berganda bermaksud meramalkan bagaimana keadaan (naik turunnya) variabel dependen, bila dua atau lebih variabel independen sebagai faktor prediator dimanipulasi (dinaik turunkan nilainya).

3. Analisis korelasi sederhana Syofian (2013), analisis korelasi sederhana digunakan untuk mengetahui seberapa erat hubungan antara variabel independent dengan variabel dependent.

4. Analisis korelasi ganda (multiple correlation) merupakan angka yang menunjukkan arah dan kuatnya hubungan antara dua variabel independen secara bersama-sama atau lebih dengan satu variabel dependen.

5. Koefisien determinan atau koefisien penentu, Sugiyono (2013) koefisien ini disebut koefisien penentu, karena varians yang terjadi pada variabel dependen dapat dijelaskan melalui varians yang terjadi pada variabel independen.

\section{PEMBAHASAN}

\subsection{Analisis Pengaruh Kinerja karyawan ter- hadap Kepuasan Pengguna Jasa}

Analisis regresi linier sederhana digunakan untuk mendapatkan hubungan matematis dalam bentuk suatu persamaan antara variabel tak bebas dengan variabel tunggal.

Tabel 1. Persamaan Regresi Sederhana Variabel Kinerja Karyawan (X1) Terhadap Kepuasan Pengguna Jasa (Y)

\begin{tabular}{|c|c|c|c|c|c|c|}
\hline \multicolumn{7}{|c|}{ Coefficients $^{\mathrm{a}}$} \\
\hline & \multirow{2}{*}{ Model } & $\begin{array}{l}\text { Unstanc } \\
\text { Coeffi }\end{array}$ & $\begin{array}{l}\text { lardized } \\
\text { cients }\end{array}$ & $\begin{array}{c}\text { Standardized } \\
\text { Coefficients }\end{array}$ & \multirow{2}{*}{$\mathrm{T}$} & \multirow{2}{*}{ Sig. } \\
\hline & & B & $\begin{array}{c}\text { Std. } \\
\text { Error }\end{array}$ & Beta & & \\
\hline \multirow[t]{3}{*}{1} & (Constant) & 5.308 & 1.707 & & 3.111 & .002 \\
\hline & TOTAL KK & .937 & .068 & .815 & 13.695 & .000 \\
\hline & \multicolumn{6}{|c|}{ a. Dependent Variable: TOTAL KPJ } \\
\hline
\end{tabular}

Berdasarkan perhitungan menggunakan SPSS 25 pada tabel di atas diketahui nilai a (constant) sebesar 5.308 sedangkan nilai kinerja karyawan (b / koefisien regresi) sebesar 0,937. Maka dapat dibuat persamaan regresi sederhana sebagai berikut:

$\mathrm{Y}=\mathrm{a}+\mathrm{bX}$

$\mathrm{Y}=5.308+0,937 \mathrm{X}_{1}$

Persamaan di atas dapat diartikan sebagai berikut:

1. Konstanta sebesar 5.308, mengandung arti bahwa nilai konsisten variabel kepuasan pengguna jasa adalah 5.308

2. Koefisien regresi $X$ sebesar 0.937 menyatakan bahwa setiap penambahan satu satuan Kinerja Karyawan, maka nilai Kepuasan pengguna jasa bertambah sebesar 0.937. Koefisien regresi tersebut bernilai positif, sehingga dapat dikatakan bahwa arah pengaruh variabel $\mathrm{X} 1$ terhadap $\mathrm{Y}$ adalah positif.

\section{Uji t}

Untuk menguji hipotesis atau dugaan adanya pengaruh antara masing-masing variabel dimana variabel Kinerja Karyawan (X1) memberikan pengaruh terhadap variabel Kepuasan Pengguna Jasa (Y). Dalam penelitian ini penulis menggunakan uji hipotesis dengan tingkat signifikansi sebesar 5\% atau $\alpha=0,05$ Dengan $\mathrm{df}=\mathrm{n}-1$. Adapaun untuk pengambilan keputusan dengan membandingkan nilai $t_{\text {hitung }}$ dan $t_{\text {tabel. }}$.

a. Jika $t_{\text {hitung }}<\mathrm{t}_{\text {tabel }}$ maka Ho diterima dan Ha di tolak, yang berarti tidak adanya hubungan antara $\mathrm{x} 1$ dan Y.

b. Jika $t_{\text {hitung }}>t_{\text {tabel }}$ maka Ho ditolak dan Ha diterima, yang berarti adanya hubungan antara $\mathrm{x} 1$ dan $\mathrm{Y}$. 
Berdasarkan ketentuan di atas maka penulis dapat melakukan pengujian dengan menggunkan SPSS Versi 25.

Tabel 2. Hasil Uji Signfikansi Persial (Uji t)

\begin{tabular}{|c|c|c|c|c|c|c|}
\hline \multicolumn{7}{|c|}{ Coefficients $^{\mathrm{a}}$} \\
\hline & \multirow{2}{*}{ Model } & \multicolumn{2}{|c|}{ Coefficients } & \multirow{2}{*}{$\begin{array}{c}\begin{array}{c}\text { Standardized } \\
\text { Coefficients }\end{array} \\
\text { Beta }\end{array}$} & \multirow{2}{*}{$\mathrm{T}$} & \multirow{2}{*}{ Sig. } \\
\hline & & B & $\begin{array}{c}\text { Std. } \\
\text { Error }\end{array}$ & & & \\
\hline \multirow[t]{2}{*}{1} & (Constant) & 5.308 & 1.707 & & 3.111 & .002 \\
\hline & TOTALKK & .937 & .068 & .815 & 13.695 & .000 \\
\hline \multicolumn{7}{|c|}{ a. Dependent Variable: TOTALKPJ } \\
\hline
\end{tabular}

Sumber: data diolah oleh penulis menggunakan SPSS 25

Berdasarkan table diatas dapat diketahui nilai Signifikansi untuk pengaruh variabel kinerja Karyawan (X1) terhadap Kepuasan Pengguna Jasa (Y) sebesar $0,000<0,05$ dan nilai thitung sebesar 13,695 . Setelah nilai $t_{\text {hitung }}$ diketahui maka dapat di cari nilai $t_{\text {tabel }}$ dengan menggunakan persamaan sebagai berikut:

Taraf nyata $(\alpha)=0,05$

Derajat kebebasan (df) sebesar $\mathrm{n}-2=97-2=95$

Dari data tersebut maka dapat diperoleh nilai t tabel sebesar 1.985 yang berati $t$ hitung $>t$ tabel $(13,695>$ 1,985) dari hasil tersebut membuktikan maka $\mathrm{H}_{0}$ ditolak dan $\mathrm{H}_{\mathrm{a}}$ diterima yang memiliki arti bahwa variabel Kinerja Karyawan (X1) memberikan pengaruh yang positif dan signfikan terhadap variabel Kepuasan Pengguna Jasa (Y).

\subsection{Analisis Pengaruh Kualitas Pelayanan ter- hadap Kepuasan pengguna jasa}

Analisis Regresi Linear Sederhana, berdasarkan perhitungan menggunakan SPSS 25 pada tabel di atas diketahui nilai a (constant) sebesar 1,770 sedangkan nilai Kualitas Pelayanan (b / koefisien regresi) sebesar 0.465 . Maka dapat dibuat persamaan regresi sederhana sebagai berikut:

$\mathrm{Y}^{\prime}=\mathrm{a}+\mathrm{bX}_{2}$

$\mathrm{Y}=1,770+0.465 \mathrm{X}_{2}$

Tabel 3. Persamaan Regresi Sederhana Variabel Kualitas Pelayanan (X2) terhadap kepuasan Pengguna Jasa (Y)

\begin{tabular}{|c|c|c|c|c|c|}
\hline \multicolumn{6}{|c|}{ Coefficients $^{\mathrm{a}}$} \\
\hline \multirow[t]{2}{*}{ Model } & $\begin{array}{l}\text { Unstanc } \\
\text { Coeff }\end{array}$ & $\begin{array}{l}\text { lardized } \\
\text { cients }\end{array}$ & $\begin{array}{l}\text { Standardized } \\
\text { Coefficients }\end{array}$ & \multirow[b]{2}{*}{$\mathrm{T}$} & \multirow[b]{2}{*}{ Sig. } \\
\hline & B & $\begin{array}{l}\text { Std. } \\
\text { Error }\end{array}$ & Beta & & \\
\hline 1 (Constant) & 1.770 & 1.610 & & 1.100 & .274 \\
\hline TOTAL KP & .465 & .028 & .864 & 16.711 & .000 \\
\hline \multicolumn{6}{|c|}{ a. Dependent Variable: TOTALKPJ } \\
\hline
\end{tabular}

Sumber: data diolah penulis menggunakan SPSS 25
Persamaan diatas dapat diartikan sebagai berikut:

1. Konstanta sebesar 1,770, mengandung arti bahwa nilai konsisten variabel Kepuasan Pengguna Jasa adalah 1,770

2. Koefisien regresi $X$ sebesar 0,465 menyatakan bahwa setiap penambahan satu kesatuan Kualitas Pelayanan, maka nilai Kepuasan Pengguna Jasa bertambah sebesar 0.465 . Koefisien regresi tersebut bernilai positif, sehingga dapat dikatakan bahwa arah pengaruh variable Kualitas Pelayanan X2 terhadap Y adalah positif.

\section{Uji T}

Untuk menguji hipotesis atau dugaan adanya pengaruh antara masing-masing variabel dimana variabel Kualitas Pelayanan (X2) memberikan pengaruh terhadap variabel Kepuasan Pengguna Jasa (Y). Dalam penelitian ini penulis menggunakan uji hipotesis dengan tingkat signifikansi sebesar 5\% atau $\alpha=0,05$ Dengan $\mathrm{df}=\mathrm{n}-1$.

Adapaun untuk pengambilan keputusan dengan membandingkan nilai thitung dan $t_{\text {tabel. }}$.

a. Jika $\mathrm{t}_{\text {hitung }}<\mathrm{t}$ tabel maka Ho diterima dan $\mathrm{Ha}$ di tolak, yang berarti tidak adanya hubungan antara $\mathrm{X} 2$ dan $\mathrm{Y}$.

b. Jika $t_{\text {hitung }}>t_{\text {tabel }}$ maka Ho ditolak dan Ha diterima, yang berarti adanya hubungan antara X2 dan Y.

Berdasarkan ketentuan diatas maka penulis dapat melakukan pengujian dengan menggunkan SPSS Versi 25 .

Tabel 4. Hasil Uji Signifikansi persial (Uji t)

\begin{tabular}{|c|c|c|c|c|c|c|}
\hline \multicolumn{7}{|c|}{ Coefficients $^{\mathrm{a}}$} \\
\hline & \multirow{2}{*}{ Model } & $\begin{array}{r}\text { Unstan } \\
\text { Coef }\end{array}$ & $\begin{array}{l}\text { lardized } \\
\text { cients }\end{array}$ & $\begin{array}{c}\text { Standardized } \\
\text { Coefficients }\end{array}$ & \multirow{2}{*}{$\mathrm{t}$} & \multirow{2}{*}{ Sig. } \\
\hline & & B & $\begin{array}{c}\text { Std. } \\
\text { Error }\end{array}$ & Beta & & \\
\hline \multirow[t]{2}{*}{1} & (Constant) & 1.770 & 1.610 & & 1.100 & .274 \\
\hline & TOTAL KP & .465 & .028 & .864 & 16.711 & .000 \\
\hline \multicolumn{7}{|c|}{ a. Dependent Variable: TOTALKPJ } \\
\hline
\end{tabular}

Berdasarkan perhitungan menggunakan SPSS 25 pada tabel diatas mengenai Persamaan Regresi Sederhana Variabel kualitas pelayanan (X2) Terhadap kepuasan pengguna jasa (Y) dapat diketahui nilai Signifikansi untuk pengaruh variabel kualitas pelayanan $(\mathrm{X} 2)$ terhadap Kepuasan pengguna jasa (Y) sebesar $0.000<0.05$ dan nilai t hitung sebesar 16.711 . Setelah nilai $t_{\text {hitung }}$ diketahui maka dapat di cari nilai $t_{\text {tabel }}$ dengan menggunakan persamaan sebagai berikut:

Taraf nyata $(\alpha)=0.05$

Derajad kebebasan (df) sebesar $\mathrm{n}-2=97-2=95$ 
Dari data tersebut maka dapat diperoleh nilai $t$ tabel sebesar 1.985 yang berati t hitung > t tabel $(16,711>$ 1,985) dari hasil tersebut membuktikan maka $\mathrm{H}_{0}$ ditolak dan $\mathrm{H}_{\mathrm{a}}$ diterima yang memiliki arti bahwa variabel kualitas pelayanan (X2) memberikan pengaruh yang positif dan signfikan terhadap variabel Kepuasan Pengguna Jasa (Y).

Berdasarkan hasil perhitungan dengan SPSS 25 pada tabel di bawah ini diperoleh nilai a sebesar 1.533; nilai $b_{1}$ sebesar 0,264; dan nilai $b_{2}$ sebesar 0,355 untuk persamaan regresi linear berganda sebagai berikut:

$\mathrm{Y}=1.533+0,264 \mathrm{X}_{1}+0,355 \mathrm{X}_{2}$

Keterangan:

1) Nilai konstanta bernilai positif, hal ini menunjukkan apabila Kinerja Karyawan $\left(\mathrm{X}_{1}\right)$ dan Kualitas pelayanan $\left(\mathrm{X}_{2}\right)$ dianggap konstan, maka Kepuasan Pengguna Jasa (Y) pada Unit Pengelola Pengujian Kendaraan Bermotor Pulogadung nilainya 1.533.

2) Koefisien regresi Kinerja Karyawan bernilai positif, hal ini menunjukkan bahwa apabila Kinerja Karyawan $\left(\mathrm{X}_{1}\right)$ meningkat maka Kepuasan Pengguna Jasa (Y) meningkat. Artinya setiap ada peningkatan pada satu satuan Kinerja Karyawan maka mengakibatkan Kepuasan Pengguna Jasa meningkat sebesar 0,264.

3) Koefisien regresi Kualitas Pelayanan bernilai positif, hal ini menunjukkan bahwa apabila kualitas pelayanan $\left(\mathrm{X}_{2}\right)$ meningkat maka Kepuasan Pengguna Jasa (Y) meningkat. Artinya setiap ada peningkatan pada kualitas pelayanan maka mengakibatkan Kepuasan Pengguna Jasa meningkat sebesar 0,355.

Tabel 5. Regresi Berganda kinerja Karyawan (X1) dan Kualitas Pelayanan (X2) Terhadap Kepuasan pengguna jasa (Y)

\begin{tabular}{|c|c|c|c|c|c|}
\hline \multicolumn{6}{|c|}{ Coefficients $^{\mathrm{a}}$} \\
\hline \multirow{2}{*}{ Model } & $\begin{array}{l}\text { Unstan } \\
\text { Coeff }\end{array}$ & $\begin{array}{l}\text { ardized } \\
\text { cients }\end{array}$ & $\begin{array}{l}\text { Standardized } \\
\text { Coefficients }\end{array}$ & \multirow{2}{*}{$\mathrm{T}$} & \multirow{2}{*}{ Sig. } \\
\hline & B & $\begin{array}{l}\text { Std. } \\
\text { Error }\end{array}$ & Beta & & \\
\hline \multirow{3}{*}{$\begin{array}{l}\text { lConstant) } \\
\text { TOTALKK } \\
\text { TOTALKF }\end{array}$} & 1.533 & 1.586 & & 966 & .336 \\
\hline & .264 & .126 & 230 & 2.097 & .039 \\
\hline & .355 & .059 & 660 & 6.027 & .000 \\
\hline \multicolumn{6}{|c|}{ a. Dependent Variable: TOTALKPJ } \\
\hline
\end{tabular}

\section{Uji F}

Uji F dilakukan menggunakan SPSS 25 untuk mengetahui hubungan regresi secara simultan dengan bertujuan guna mengetahui apakah seluruh variabel independen $\left(\mathrm{X}_{1}\right.$ dan $\left.\mathrm{X}_{2}\right)$ secara bersama-sama memiliki pengaruh yang signifikan terhadap variabel dependen (Y).
Tabel 6. Rekapitulasi hasil Uji F (Uji Global)

\begin{tabular}{|c|c|c|c|c|c|}
\hline \multicolumn{6}{|c|}{ ANOVA $^{\mathbf{a}}$} \\
\hline Model & $\begin{array}{l}\text { Sum of } \\
\text { Squares }\end{array}$ & Df & $\begin{array}{l}\text { Mean } \\
\text { Square }\end{array}$ & $\mathrm{F}$ & Sig. \\
\hline 1 Regression & 1273.992 & 2 & 636.996 & 146.823 & $.000^{\mathrm{b}}$ \\
\hline Residual & 407.823 & 94 & 4.339 & & \\
\hline Total & 1681.814 & 96 & & & \\
\hline \multicolumn{6}{|c|}{ a. Dependent Variable: TOTALKPJ } \\
\hline \multicolumn{6}{|c|}{ b. Predictors: (Constant), TOTALKK, TOTALKP } \\
\hline
\end{tabular}

Sumber: Output data pengolahan SPSS 25

Berdasarkan Tabel diatas nilai $\mathrm{F}_{\text {hitung }}$ adalah sebesar 146,823 . Nilai $F_{\text {tabel }}$ dapat dicari dengan persamaan $\mathrm{df}$ $1=$ jumlah variabel bebas. Artinya df $1=2$, sedangkan df $2=n-k-1(97-2-1)=94$. Dengan menggunakan signifikasi $5 \%$ atau $(0,05)$ dan pengujian dua sisi maka signifikasi $0,05: 2=0,025$, dapat dilihat $\mathrm{F}_{\text {tabel }}$ sebesar 3.09. Berdasarkan hasil dalam perhitungan tersebut maka dapat disimpulkan bahwa nilai $F_{\text {hiung }}$ $>\mathrm{F}_{\text {tabel }}(146,823>3.09)$ atau $0,000<0,05$ sehingga $\mathrm{H}_{0}$ ditolak dan $\mathrm{H}_{\mathrm{a}}$ diterima, artinya variabel Kinerja Karyawan $\left(\mathrm{X}_{1}\right)$ dan Kualitas Pelayanan $\left(\mathrm{X}_{2}\right)$ secara global mempunyai pengaruh yang signifikan terhadap Kepuasan pengguna jasa (Y).

\section{SIMPULAN}

Kinerja Karyawan Terhadap Kepuasan Pengguna jasa, hasil penelitian ini menunjukkan bahwa secara parsial terdapat pengaruh signifikan terhadap Kinerja karyawan terhadap Kepuasan pengguna jasa pada Unit Penggelola Pengujian Kendaraan Bermotor Pulogadung. Persamaan variabel kinerja karyawan dengan kepuasaan pengguna jasa yaitu $\mathrm{Y}=5.308+$ $0,937 \mathrm{X}_{1}$ dengan nilai kontribusi pengaruh variabel sebesar $66,4 \%$. Hasil ini diterima dari responden yang telah menjawab pertanyaan melalui kueisioner penelitian ini yang menghasilkan Kinerja karyawan menunjukkan nilai t hitung sebesar 13.695 dengan taraf signifikan sebesar 0,000 lebih kecil dari 0,05 yang berarti bahwa dalam penelitian ini Kinerja karyawan berdeterminasi secara signifikan terhadap Kepuasan pengguna jasa pada Unit Penggelola Penggujian Kendaraan Bermotor Pulogadung. Hasil tersebut diperkuat dengan penelitian terdahulu yang ditulis oleh Eno Virgiawansyah dengan judul pengaruh kinerja karyawan terhadap kepuasan konsumen rental mobil yang menyatakan bahwa variable kinerja karyawan memiliki koefisien regresi sebesar 0,197 (bertanda positif) terhadap kepuasan konsumen $(\mathrm{Y})$ dan nilai thitung sebesar 2,318 dengan tingkat signifikansi $0,023<0,05$, hal ini berarti bahwa kinerja karyawan berpengaruh positif terhadap kepuasan konsumen. 
Kualitas pelayanan Terhadap Kepuasan Pengguna Jasa, hasil penelitian ini menunjukkan bahwa secara parsial terdapat pengaruh signifikan antara Kualitas pelayanan terhadap Kepuasan Pengguna jasa pada Unit Penggelola Penggujian Kendaraan Bermotor Pulogadung. Persamaan variabel kualitas pelayanan dengan kepuasaan pengguna jasa yaitu $\mathrm{Y}=1,770+$ $0.465 \mathrm{X} 2$ dengan nilai kontribusi pengaruh variabel sebesar $74.6 \%$. Hasil ini diterima dari responden yang telah menjawab pertanyaan melalui kueisioner penelitian ini yang menghasilkan Kualitas Pelayanan menunjukkan nilai $\mathrm{t}$ hitung sebesar 16.711 dengan taraf signifikan sebesar 0,000 lebih kecil dari 0,05 yang berarti bahwa dalam penelitian ini Kualitas Pelayanan secara parsial berdeterminasi signifikan terhadap Kepuasan Pengguna Jasa pada Unit Pengelola Pengujian Kendaraan Bermotor Pulogadung. Hasil tersebut diperkuat dengan hasil penelitian terdahulu yang ditulis oleh Alfi Syari Lubis dan Nur Rahma dengan judul pengaruh kualitas pelayanan terhadap kepuasan pelanggan PT. Sucofindo Batam bahwa variabel kualitas pelayanan X1 mempunyai pengaruh yang positif dan signifikan terhadap kepuasan pelanggan $\mathrm{Y}$.

\section{DAFTAR PUSTAKA}

Afifah, A. (2017). Pengaruh Kualitas Pelayanan dan Kinerja Terhadap Kepuasan Penumpang Jasa Airport Helper di Terminal 1 Bandar SoekarnoHatta Yahun 2017. Institut Tranportasi dan Logistik Trisakti.

Aptaguna, A., \& Pitaloka, E. (2016). Pengaruh Kualitas Layanan Dan Harga Terhadap Minat Beli Jasa Go-Jek. Widyakala Journal, 3(2012), 49. https://doi.org/10.36262/widyakala.v3i0.24

Bisri, H. (n.d.). Terhadap Lemahnya Standart Operating Procedures pada UPTD Uji Kir Dinas.

Chasanah, D., \& Suprajang, E. (n.d.). Analisis Kepuasan Konsumen melalui Kualitas Pelayanan Uji Kir pada Dinas Perhubungan Kabupaten Blitar. 64-80.

Damayanti, R., Hanafi, A., \& Cahyadi, A. (2018). Pengaruh Kepuasan Kerja Terhadap Kinerja Karyawan (Studi Kasus Karyawan Non Medis RS Islam Siti Khadijah Palembang) Riski Damayanti 1, Agustina Hanafi 2, \& Afriyadi
Cahyadi 3. L Ilmiah Manajemen Bisnis Dan Terapan Tahun, 2, 75-86.

Haryanto, E. (2013). Kualitas Layanan, Fasilitas Dan Harga Pengaruhnya Terhadap Kepuasan Pengguna Jasa Layanan Pada Kantor Samsat Manado. Jurnal Riset Ekonomi, Manajemen, Bisnis Dan Akuntansi, 1(3), 750-760. https://doi.org/ 10.35794/emba.vli3.2212

Meriyadi, A., Ali, M., \& Jusni. (2019). Strategi Membangun Loyalitas Pelanggan Untuk Mencapai Keunggulan Bersaing Pada PT. Semen Tonasa Kabupaten Pangkep. Journal Of Management, 1(1), 1-8.

Philip kotler, \& Keller, kevin lane. (2010). manajemen pemasaran (13th ed., pp. 138-139). erlangga.

Prasadja Ricardianto. (2018). human capital management. in media.

Puung, F. K., Fudholi, A., \& Dharmmesta, B. S. (2014). Analisis Pengaruh Kualitas Pelayanan Pada Kepuasan dan Loyalitas Pelanggan di Salon dan Spa. Analisis Pengaruh Kualitas Pelayanan pada Kepuasan dan Loyalitas Pelanggan di Salon dan Spa, 4(2), 105-110. https://doi. org/10.22146/jmpf.274

Rohaeni, H., \& Marwa, N. (2018). Kualitas Pelayanan Terhadap Kepuasan Pelanggan. Jurnal Ecodemica: Jurnal Ekonomi, Manajemen, Dan Bisnis, 2(2), 1-7. https://doi.org/10.31311/ECO. V2I2.4503

Samsudin, H. (2018). Kinerja Karyawan. Indomedia Pustaka.

Santoso, A. (2019). Analisis Kualitas Pelayanan Uji Kir Terhadap Kepuasan Masyarakat Pengguna Jasa Kir Di Dinas Perhubungan Kota Kediri. Jurnal Mediasosian: Jurnal Ilmu Sosial Dan Administrasi Negara, 2(1), 46-50. https://doi. org/ 10.30737/mediasosian.v2i1.206

Tanod, D. P., Nofrisel, Toelle, S., \& Handayani, S. (2018). Impact Quality of Service and Customer Value of Customer Loyalty (Survey on PT. DHL Global Forwarding Customer, Jakarta). Advances in Transportation and Logistics Research, 1(1), 668-681. https://doi.org/10.25292/ atlr.vli1.64

Yuliana, W., \& Febriyani, E. (2018). Pengaruh Kualitas Pelayanan dan Tarif terhadap Minat Beli Penumpang Bus Damri Unit Angkutan Kota Bandung. In Jurnal Ekonomi Manajemen (Vol. 4, Issue ISSN 2477-2275). 